\title{
Seasonal Variation and Assessment of Fish Resources in the Yangtze Estuary Based on Environmental DNA
}

\author{
Hui Jia ${ }^{1,2,3,4}$, Yibang Wang ${ }^{1,2,3}$, Susumu Yoshizawa ${ }^{5}$, Wataru Iwasaki ${ }^{5,6}$, Yuquan Li ${ }^{4}$, \\ Weiwei Xian $1,2,3, *$ and Hui Zhang $1,2,3,5, *$ (D) \\ 1 CAS Key Laboratory of Marine Ecology and Environmental Sciences, Institute of Oceanology, Chinese \\ Academy of Sciences, Qingdao 266071, China; jiahui@qdio.ac.cn (H.J.); wangyibang@qdio.ac.cn (Y.W.) \\ 2 Laboratory for Marine Ecology and Environmental Science, Qingdao National Laboratory for Marine \\ Science and Technology, Qingdao 266237, China \\ 3 Center for Ocean Mega-Science, Chinese Academy of Sciences, Qingdao 266071, China \\ 4 School of Marine Science and Engineering, Qingdao Agricultural University, Qingdao 266109, China; \\ jiangfangqian@163.com \\ 5 Atmosphere and Ocean Research Institute, the University of Tokyo, Kashiwa, Chiba 277-8564, Japan; \\ yoshizawa@aori.u-tokyo.ac.jp (S.Y.); iwasaki@bs.s.u-tokyo.ac.jp (W.I.) \\ 6 Department of Biological Sciences, Graduate School of Science, the University of Tokyo, Bunkyo-ku, \\ Tokyo 113-0032, Japan \\ * Correspondence: wwxian@qdio.ac.cn (W.X.); zhanghui@qdio.ac.cn (H.Z.); Tel.: +86-532-82898594 (W.X.); \\ +86-532-82891860 (H.Z.)
}

Received: 28 August 2020; Accepted: 12 October 2020; Published: 16 October 2020

\begin{abstract}
In the past few years, environmental DNA (eDNA) techniques have been used to monitor marine communities. Research indicates that eDNA is an effective tool for monitoring fishery resources. This study analyzed the seasonal variations in fish resources in the Yangtze Estuary, China, using eDNA. A total of 103 water samples were collected from the Yangtze Estuary across the four seasons in 2019-20 samples in February, 28 in May, 28 in August and 27 in November. Our research successfully detected the fishery resources of the Yangtze Estuary. We found significant differences according to the season. The results showed that 59 species were identified in 2019 (20 in February, 16 in May, 5 in August and 45 in November) and fish species varied widely over the four seasons. Furthermore, our samples revealed significant differences in annual fish stocks in the Yangtze Estuary, compared with eDNA data from 2018 and with traditional surveys from past years. Overall, eDNA is a useful emerging tool to assist with monitoring and protecting fish resources for the Yangtze Estuary.
\end{abstract}

Keywords: Yangtze Estuary; environmental DNA; marine fish; seasonal variation; fish assessment

\section{Introduction}

The Yangtze Estuary is a densely populated and rapidly developing region, with two major fishing industries: Zhoushan Fishery in the south and Lvsi Fishery in the north. The large estuary contains abundant nutrients and habitats where many fish breed, fatten and migrate [1]. In recent years, development of the fishing industry has affected the fish resources of the Yangtze Estuary, through ecological destruction, biodiversity reduction and environmental degradation [2]. The sustainable use and protection of the Yangtze Estuary has become the focus of attention [1]. Understanding and monitoring its fish resources are prerequisites for the estuary's protection [3]. However, because of the large range of many marine fishes and the changeable aquatic environment, their occurrence and distribution are not fully understood. It is technically difficult to carry out comprehensive ecological monitoring, and traditional monitoring and investigation methods can also cause some harm to the fish [4]. 
Environmental DNA (eDNA) is a non-invasive technique for monitoring endangered, invasive, or protected target species. It concentrates the DNA molecules shed into the environment (such as water, soil, air, or snow) to a level that can be detected by PCR. It provides complete biological information through methods such as high-throughput sequencing, which is a quick and effective monitoring technology [5]. DNA reaches the environment through two pathways. First, intracellular DNA is released by organisms into the environment through mucus, feces, urine and skin; second, extracellular DNA is released into the environment after death [6]. The eDNA technique was first explicitly proposed by Rondon et al. in soil microbial studies [7]. Ficetola et al. detected the presence of Rana Catesbeiana in freshwater using eDNA techniques, which was the first use of the method to monitor aquatic creatures [8]. Takahara et al. demonstrated that the number of carp was linearly related to the concentration of eDNA [9]. Since then, researchers have used eDNA techniques to monitor the biodiversity and biomass of many species. Kelly et al. successfully analyzed the marine species community composition of an aquarium through sequencing techniques [10]. Forsström et al. expanded the scope of eDNA marine targets by implementing eDNA techniques for monitoring aquatic invertebrates in the Baltic Sea [11]. Stat et al. applied eDNA barcoding to monitor the biodiversity of marine species, which verified that eDNA was useful for monitoring fish biodiversity [12]. Cowart et al. successfully analyzed the composition of the marine invertebrate community using eDNA [13]. Kimmerling et al. conducted eDNA monitoring of the biomass of young reef fish and analyzed their distribution characteristics [14]. Furthermore, eDNA barcoding was used to determine the distribution of species in different marine habitats and successfully analyzed the structural characteristics of marine biological communities [15]. Recently, eDNA was used to assess the species diversity of a tropical island coral reef in Australia, providing a technical reference for future coral reef monitoring [16]. This research suggests that eDNA techniques provide a new method for monitoring aquatic organisms.

eDNA techniques detect small amounts of DNA in water samples and gradually as a method to assess the diversity of macro-organismal communities in natural ecosystems [17]. Over the past few years, eDNA techniques have proven to be successful in monitoring the presence/absence of rare, endangered, protected and invasive species, assessing biodiversity and determining species distribution, population dynamics, ecosystem health and other applications [18]. For instance, Yamanaka et al. monitored the habitat of the rare Japanese Acheilognathus typus by eDNA techniques [19]. The development of large-scale parallel sequencing makes it possible to detect the DNA sequences of a variety of organisms in a single reaction and to identify the species living in the investigated area by comparing them with the gene sequences in GenBank [20]. Besides, many studies have applied eDNA techniques to the detection of biodiversity and biomass. Evans et al. determined that the sequence copy number was positively correlated with the abundances of nine freshwater species via eDNA metabarcoding [21]. Lacoursière-Roussel et al. investigated the abundance of lake trout by eDNA techniques, compared with traditional fishing methods, and concluded that the eDNA technique was advantageous and that the reliability of eDNA techniques was verified successfully [22]. Doi et al. demonstrated a relationship between the concentration of eDNA techniques and the abundance and biomass of ayu Plecoglossus altivelis in the Zopo River of Japan [23]. Thalinger et al. quantitatively tracked migratory fish by eDNA techniques in a large river, and it appeared to be a reliable, cost-effective method for future monitoring of ecological distribution [19]. Up until now, ecological monitoring has faced technical difficulties in the marine environment because of complex communities, cryptic living environments and fish movements; eDNA techniques may well solve many of these problems [24]. As a biodiversity monitoring tool, eDNA techniques have the advantage of establishing species diversity and richness without relying on morphological classification and distribution [25]. At present, studies have shown that eDNA techniques can be used to carry out comprehensive surveys of marine biomes [26].

The purpose of this study was to use eDNA techniques to investigate changing seasonal trends in fish resources in the Yangtze Estuary in 2019, which can provide a new monitoring technology for fish resources in this region. Additionally, the annual change of fish resources in the Yangtze Estuary was 
analyzed, by comparing the results found here with eDNA data from 2018 and with traditional surveys from previous years. The results provided a data reference for future studies on monitoring and protecting fish resources in the Yangtze Estuary. Our study is important for the further development of eDNA methods and can build the basis to monitor fish resources.

\section{Materials and Methods}

\subsection{Study Sites and Samples Collection}

A total of 103 environmental DNA samples were collected from the Yangtze Estuary and its adjacent waters in 2019. For seasonal analysis, 20 samples were collected in February (winter), 28 in May (spring), 28 in August (summer), and 27 in November (autumn).

A total of 30 stations were used through the year and the stations in four trips were slightly different because the sea conditions affected the suitability of sampling sites over the survey trips (Table 1). The equipment was strictly sterilized to prevent water samples from being contaminated. Water samples were collected on four survey trips. According to the marine survey specifications, 1-2 L of water was taken from the surface water layers and sealed in brown jars for immediate filtration in the laboratory [27]. We collected the surface water samples using a bucket. The sampling sites for each trip are shown in Figure 1.

Table 1. Sampling sites coordinates ("+" represents the station fetched on each voyage).

\begin{tabular}{ccccccc}
\hline Station & Longitude & Latitude & Winter & Spring & Summer & Autumn \\
\hline 1 & $122^{\circ} 33^{\prime}$ & $32^{\circ} 00^{\prime}$ & & + & + & + \\
2 & $122^{\circ} 67^{\prime}$ & $32^{\circ} 00^{\prime}$ & & + & + & + \\
3 & $123^{\circ} 00^{\prime}$ & $32^{\circ} 00^{\prime}$ & & + & + & + \\
4 & $123^{\circ} 33^{\prime}$ & $32^{\circ} 00^{\prime}$ & & + & + & + \\
5 & $122^{\circ} 33^{\prime}$ & $31^{\circ} 75^{\prime}$ & & + & + & + \\
6 & $122^{\circ} 67^{\prime}$ & $31^{\circ} 75^{\prime}$ & + & + & + & + \\
7 & $123^{\circ} 00^{\prime}$ & $31^{\circ} 75^{\prime}$ & + & + & + & + \\
8 & $123^{\circ} 33^{\prime}$ & $31^{\circ} 75^{\prime}$ & + & + & + & + \\
9 & $122^{\circ} 17^{\prime}$ & $31^{\circ} 50^{\prime}$ & & + & + & + \\
10 & $122^{\circ} 33^{\prime}$ & $31^{\circ} 50^{\prime}$ & & + & + & + \\
11 & $122^{\circ} 50^{\prime}$ & $31^{\circ} 50^{\prime}$ & + & + & + & + \\
12 & $122^{\circ} 67^{\prime}$ & $31^{\circ} 50^{\prime}$ & + & + & + & + \\
13 & $123^{\circ} 00^{\prime}$ & $31^{\circ} 50^{\prime}$ & + & + & + & + \\
14 & $122^{\circ} 17^{\prime}$ & $31^{\circ} 25^{\prime}$ & + & + & + & + \\
15 & $122^{\circ} 33^{\prime}$ & $31^{\circ} 25^{\prime}$ & + & + & + & + \\
16 & $122^{\circ} 50^{\prime}$ & $31^{\circ} 25^{\prime}$ & + & + & + & + \\
17 & $122^{\circ} 67^{\prime}$ & $31^{\circ} 25^{\prime}$ & + & + & + & + \\
18 & $123^{\circ} 00^{\prime}$ & $31^{\circ} 25^{\prime}$ & + & + & + & + \\
19 & $123^{\circ} 33^{\prime}$ & $31^{\circ} 25^{\prime}$ & & + & + & + \\
20 & $122^{\circ} 00^{\prime}$ & $31^{\circ} 13^{\prime}$ & + & + & + & + \\
21 & $122^{\circ} 00^{\prime}$ & $31^{\circ} 00^{\prime}$ & + & + & + & + \\
22 & $122^{\circ} 17^{\prime}$ & $31^{\circ} 00^{\prime}$ & + & + & + & + \\
23 & $122^{\circ} 33^{\prime}$ & $31^{\circ} 00^{\prime}$ & + & + & + & + \\
24 & $122^{\circ} 50^{\prime}$ & $31^{\circ} 00^{\prime}$ & + & + & + & + \\
25 & $122^{\circ} 67^{\prime}$ & $31^{\circ} 00^{\prime}$ & + & + & + & + \\
26 & $123^{\circ} 00^{\prime}$ & $31^{\circ} 00^{\prime}$ & & + & + & + \\
27 & $123^{\circ} 33^{\prime}$ & $31^{\circ} 00^{\prime}$ & & + & + & + \\
28 & $122^{\circ} 00^{\prime}$ & $30^{\circ} 75^{\prime}$ & + & + & + & + \\
29 & $122^{\circ} 17^{\prime}$ & $30^{\circ} 75^{\prime}$ & + & & & + \\
30 & $122^{\circ} 33^{\prime}$ & $30^{\circ} 75^{\prime}$ & + & + & + & + \\
\hline & & & + & + & + \\
\hline
\end{tabular}




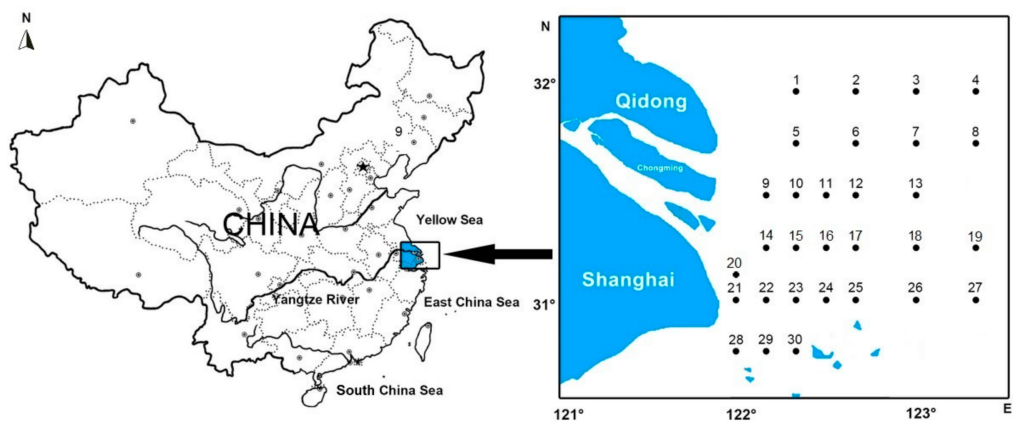

Figure 1. Sampling location (the specific station information of Yangtze Estuary was presented on the right).

We used a Sterivextex TM-GP filter unit to filter the water samples, and each water sample bottle was filtered twice to ensure adequate collection. After that, the water from the filter column was fully drained with a syringe and stored in DNA preservation buffer (Tiandz Inc., Beijing, China). To reduce experimental error and check for any experimental contamination, the filtration equal-volume deionized water was used as the negative control. Then, the original samples were stored in a freezer at $-20{ }^{\circ} \mathrm{C}$.

\section{2. eDNA Extraction, PCR Amplification and Sequencing}

The frozen original samples were sent to Personalbio (218 Yindu Road, Xuhui District, Shanghai, China) for processing on dry ice. The total DNA in the water was extracted from the Sterivex filter unit using DNeasy blood and tissue kits (Qiagen, Hilden, Germany) according to Miya et al. [28]. The extraction quality of DNA was determined by $1.2 \%$ agarose gel electrophoresis. A two-step PCR method for paired-end library preparation was used to achieve a better resolution, and a fish eDNA universal primer pair (MiFish-U/E) was used for PCR amplification [28]. To retrieve more species information, we performed each sample analysis three times and mixed all the PCR products in equal volumes. At the same time, a negative control was established to detect microbial contamination from the environment or reagent. Any negative control group that was amplified with bands was not used in subsequent experiments.

Finally, libraries were sequenced using next-generation sequencing on the Illumina MiSeq platform and an Illumina MiSeq v2 Reagent Kit was used for $2 \times 250$ bp paired-end sequencing following the manufacturer's protocol (Illumina, San Diego, CA, USA). An Agilent High-Sensitivity DNA kit was used before sequencing [25]. Then, a Quant-IT PicoGreen dsDNA Assay Kit was used to quantify the library in the Promega QuantiFluor fluorescence quantitative system. The qualified library concentration should be above $2 \mathrm{nM}$. A MiSeq Reagent Kit V3 (600 cycles) was used for double-end sequencing. Ribosomal RNA contains multiple conserved regions and highly variable regions. In general, primers that are designed to amplify single or multiple variable regions of rRNA genes are used to sequence and analyze microbial diversity. Because of MiSeq sequencing read length limitations, and to ensure sequencing quality, the optimal sequencing insert fragment range was $200-450 \mathrm{bp}$.

\subsection{Data Quality Control and Preprocessing}

Statistics were carried out on the drop-off data of each sample and the original sequencing data were stored in FASTQ format. FastQC was used for quality control of the data [25]. Sequence base quality was used to detect the average mass distribution of sequencing data. The sequencing data contained some low-quality reads, which interfered with subsequent information analysis. To ensure the quality of subsequent information analysis, it was necessary to further filter the disembarkation data to generate high-quality sequences [29]. The Dynamic Trim.Pl program (Phred Score $=10$ ) of SOLEXAQA software was used for filtering. Then, based on FLASH software, double-end reads were assembled for high-quality data, minimum overlap $=10$ [30]. The filtering conditions for the 
assembled results were as follows: first, reads containing $\mathrm{N}$ were filtered out; second, reads that were not consistent with the expected length of PCR amplification product (229 $\pm 25 \mathrm{bp}$ ) were filtered out; third, reads were removed with a primer sequence mismatch $>3 \mathrm{bp}$ based on the TAGCLEANER [26]. The total number of high-quality reads in the final four eDNA samples in 2019 were: 1,613,159 in winter, 2,551,768 in spring, 2,277,583 in summer and 3,511,365 in autumn.

\subsection{Fish Species Identification}

We used NCBI Basic Local Alignment Search Tool to verify all segments of the corresponding fish and a BLAST search was used for comparison, prior to conducting clustering [31]. QIIME2 software analysis was used for annotation screening, and the final result was compared to MitoFish, NCBI Organelle Genome Resources databases [32]. The information from the databases was merged to build a new database, using the BLASTN program [25]. The reads were clustered based on UCLUST software. Clusters of reads numbering $>10$ were used for subsequent analysis. The comparison criteria were: Identity $>95 \%$ and E-value $=10^{-5}$ [33]. Each cluster used the best comparison to obtain the final result. The combined sequences assigned to the same species were clustered and used as operational taxonomic units (OTUs) [34]. The reliability of each task was assessed at three levels: high, medium, and low [25]. Because the fragments studied were a small part of $12 \mathrm{~S} \mathrm{rRNA}$, there were sequences similar to those of other species and repeated occurrences of the same species sequence. Finally, we took into account the conditions of the Yangtze Estuary to exclude the species that should not have appeared, which were considered as experimental pollution (PCR pollution) and deleted. We used Fishbase (https://www.fishbase.se/search.php) and also consulted books about fishery resources in the Yangtze Estuary for localization certification [35]. Because of the strong biases of species composition in different seasons, we only selected the 20 most abundant species for further season biomarker analysis.

\subsection{Community Structure Diversity}

The fish sequences for each season were counted, and the frequency of the same sequence was used to represent its richness. We used alpha diversity and beta diversity indexes to characterize the diversity of species within and between habitats to comprehensively evaluate the overall diversity of the Yangtze Estuary [36,37]. The richness and evenness of fish in the Yangtze Estuary were analyzed by different index methods. The Chao 1 index was used to calculate species detected only once and twice in the community [38]. The Observed Species Index calculates the number of species in the community, and it is used to represent the richness of the community. The Simpson diversity index describes the probability that individuals sampled twice in a row from a number of species within community belong to the same species [39]. There are two components in the Shannon-Wiener index: the number of species and the evenness of distribution among individuals. Both are used to represent community diversity. Furthermore, Pielou's evenness index was used to represent the evenness, and Good's coverage index was used to represent the coverage [40]. Calculations were carried out using the diversity function in the vegan package of $\mathrm{R}$ software (v3.5.3) [25]. Dimension reduction of multidimensional data can be achieved to show the seasonal difference using nonmetric multidimensional scaling analysis (NMDS) [41]. Heat maps were used to show the difference in species composition based on average abundance ranking or the degree of similarity between the four seasons.

\subsection{Statistic Analysis}

We calculated the number of species to analyze the relationship between seasonal changes across the four annual seasons [42]. Additionally, to further compare the difference in species composition between samples in different seasons and show the distribution trend of species abundance in each sample, we conducted a random forest analysis for the 20 most abundant genera. We also investigated the lifecycle of the identified species through relevant data [35]. The statistical analysis outlined here allowed the fish species composition in different seasons in the Yangtze Estuary in 2019 to be explored [43]. The annual changes of fish in the same season were assessed by comparing the results 
of this study with the results of fish resource surveys using eDNA techniques over three seasons in 2018. Finally, to explore the temporal and spatial changes of the fish community in the Yangtze River Estuary over time, we compared our findings to the traditional surveys of the Yangtze Estuary over the past few years [44].

\section{Results}

\subsection{Fish Species}

According to statistical analysis, there were a total of 59 species of fish in the four seasons of the Yangtze Estuary in 2019, including 16 species in spring, 5 in summer, 45 in autumn and 20 in winter (Table 2). Migratory fish were indicated in the table. The random forest classifier shows the abundance of species across different samples (Figure 2). The importance of species to the model decreases from top to bottom, and the species at the top can be considered as markers of inter-group differences.

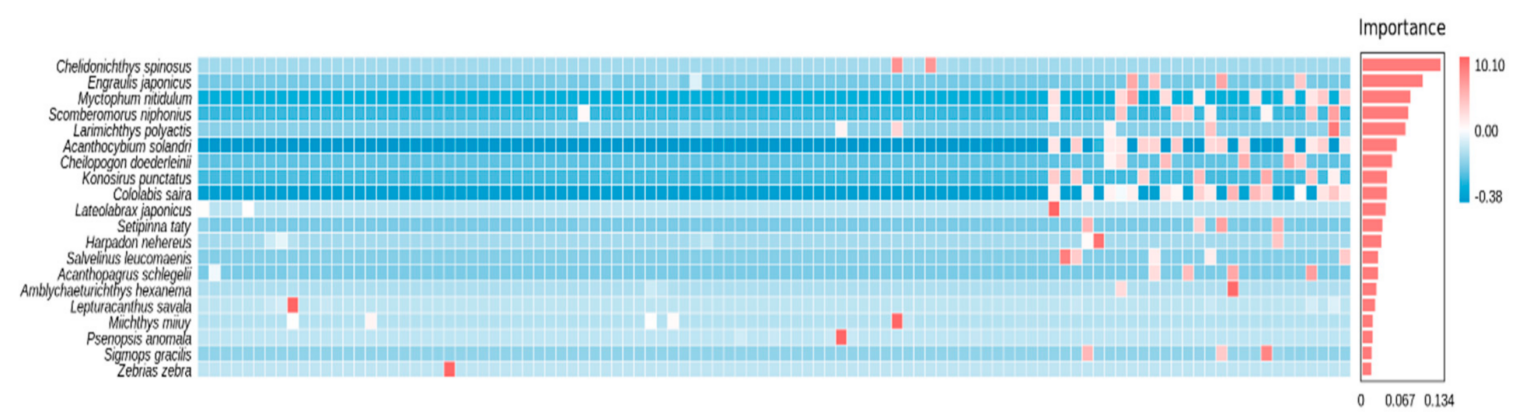

Figure 2. Importance according to the random forest analysis. From top to bottom, species become less important to the model; these species at the top of the list could be considered markers of intergroup differences; the X-axes of the bar chart shows the importance of species to the classifier mode; the Y-axes shows the name of a taxon at the species level.

The dominant fish species with random forest analysis were spiny red gurnard Chelidonichthys spinosus, Japanese anchovy Engraulis japonicus, pearly lanternfish Myctophum nitidulum, Japanese Spanish mackerel Scomberomorus niphonius, yellow croaker Larimichthys polyactis, wahoo Acanthocybium solandri, Korean flying fish Cheilopogon doederleinii, Dotted gizzard shad Konosirus punctatus, Pacific saury Cololabis saira, Japanese seabass Lateolabrax japonicus, scaly hairfin anchovy Setipinna taty, Bombay duck Harpadon nehereus, pinkgray goby Amblychaeturichthys hexanema, Savalai hairtail Lepturacanthus savala, Mi-iuy croaker Miichthys miiuy, Pacific rudderfish Psenopsis anomala, slender fangjaw Sigmops gracilis and zebra sole Zebrias zebra. 
Table 2. Species information in four seasons ("+" represents detected species; "m" represents migratory fishes).

\begin{tabular}{|c|c|c|c|c|c|}
\hline Common Name & Species & Winter & Spring & Summer & Autumn \\
\hline \multirow[t]{2}{*}{ Wahoo } & Acanthocybium solandri & & & & + \\
\hline & Acanthogobius hasta & & & & + \\
\hline Blackhead seabream & Acanthopagrus schlegelii & + & & & + \\
\hline Pinkgray goby & Amblychaeturichthys hexanema & + & + & & + \\
\hline Pacific sandlance & Ammodytes personatus & & & & + \\
\hline \multirow[t]{2}{*}{ Skinnycheek lanternfish } & Benthosema pterotum & + & & & \\
\hline & Cheilopogon doederleinii ${ }^{\mathrm{m}}$ & & & & + \\
\hline Spiny red gurnard & Chelidonichthys spinosus & & & + & \\
\hline Osbeck's grenadier anchovy & Coilia mystus $\mathrm{m}$ & + & & & \\
\hline Japanese grenadier anchovy & Coilia nasus ${ }^{\mathrm{m}}$ & + & + & & \\
\hline Pacific saury & Cololabis saira ${ }^{\mathrm{m}}$ & & & & + \\
\hline Bristlemouth & Cyclothone alba ${ }^{\mathrm{m}}$ & & & & + \\
\hline Deep-water bristlemouth & Cyclothone atraria & & & & + \\
\hline Three-lined tongue sole & Cynoglossus abbreviatus & + & + & & \\
\hline Red tonguesole & Cynoglossus joyneri & & & + & + \\
\hline Short-headed lantern fish & Diaphus brachycephalus ${ }^{\mathrm{m}}$ & & & & + \\
\hline Japanese anchovy & Engraulis japonicas $\mathrm{m}$ & & + & & + \\
\hline Spotted velvetfish & Erisphex pottii & & & & + \\
\hline Kawakawa & Euthynnus affinis $\mathrm{m}$ & & & & + \\
\hline Atlantic cod & Gadus morhua ${ }^{\mathrm{m}}$ & + & & & + \\
\hline Snake mackerel & Gempylus serpens $\mathrm{m}$ & & & & + \\
\hline Bombay-duck & Harpadon nehereus & + & + & & + \\
\hline Black-barred halfbeak & Hemiramphus far & & & & + \\
\hline Indian perch & Jaydia lineata & + & & & \\
\hline Belanger's croaker & Johnius belangerii & & + & & \\
\hline Sin croaker & Johnius grypotus & + & & & \\
\hline Dotted gizzard shad & Konosirus punctatus & + & & & + \\
\hline Slender lanternfish & Lampanyctus tenuiformis & & & & + \\
\hline Large yellow croaker & Larimichthys crocea & + & + & & + \\
\hline Yellow croaker & Larimichthys polyactis & + & + & + & + \\
\hline Japanese seabass & Lateolabrax japonicus & + & & & + \\
\hline Savalai hairtail & Lepturacanthus savala & + & & & + \\
\hline Tanaka's snailfish & Liparis tanakae $\mathrm{m}$ & & + & & + \\
\hline Yellow goosefish & Lophius litulon & + & + & & + \\
\hline Mi-iuy croaker & Miichthys miiuy & + & + & + & \\
\hline Flathead grey mullet & Mugil cephalus & & & & + \\
\hline Yellowstripe goatfish & Mulloidichthys flavolineatus & & & & + \\
\hline \multirow[t]{2}{*}{ Prickly lanternfish } & Myctophum asperum $\mathrm{m}$ & & & & + \\
\hline & Myctophum lychnobium & & & & + \\
\hline Pearly lanternfish & Myctophum nitidulum $\mathrm{m}$ & & & & + \\
\hline \multirow[t]{2}{*}{ Patchwork lampfish } & Notoscopelus resplendens $\mathrm{m}$ & & & & + \\
\hline & Odontamblyopus lacepedii & & & & + \\
\hline Scaly-nape tentacle goby & Oxyurichthys auchenolepis & & & & + \\
\hline \multirow{2}{*}{ Silver croaker } & Pennahia argentata & & + & & \\
\hline & Pholis fangi & & & & + \\
\hline Bluefin driftfish & Psenes pellucidus & & & & + \\
\hline Pacific rudderfish & Psenopsis anomala & & & + & \\
\hline Whitespotted char & Salvelinus leucomaenis $\mathrm{m}$ & & & & + \\
\hline Chub mackerel & Scomber japonicus & & & & + \\
\hline Japanese Spanish mackerel & Scomberomorus niphonius & & + & & + \\
\hline Ragged bigscale & Scopelogadus mizolepis & & & & + \\
\hline Scaly hairfin anchovy & Setipinna taty & + & + & & + \\
\hline Slender fangjaw & Sigmops gracilis & & & & + \\
\hline Japanese pufferfish & Takifugu rubripes & & & & + \\
\hline Kammal thryssa & Thryssa kammalensis $\mathrm{m}$ & & + & & \\
\hline Shokihaze goby & Tridentiger barbatus & + & & & + \\
\hline Burrowing goby & Trypauchen vagina & + & & & \\
\hline Oceanic lightfish & Vinciguerria nimbaria & & & & + \\
\hline Zebra sole & Zebrias zebra & & + & & \\
\hline
\end{tabular}




\subsection{Diversity of Fish Communities}

The alpha diversity analysis calculated in each season showed significant differences in the composition of fish in the Yangtze Estuary in 2019 (Figure 3). The summer presented the highest evenness and the winter presented the lowest. The autumn presented the highest diversity, while the spring presented the lowest richness. The seasonal assemblage structure was described by the two-dimensional sorting graph based on the NMDS analysis in Figure 4. The results showed that the distance between the points grouped in winter and spring is relatively close, indicating that the difference in community composition between the two seasons was small. The long distance between them and other seasonal groups (summer and autumn) indicated that there are significant differences in community composition.

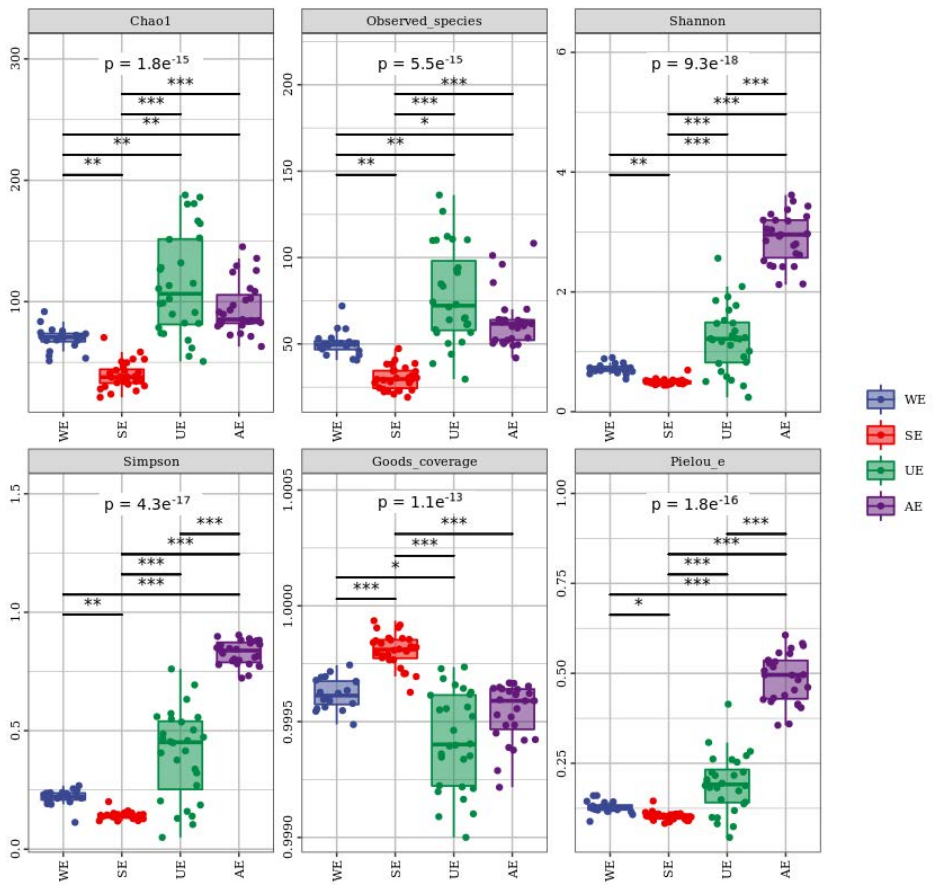

Figure 3. Seasonal difference based on the Alpha index. "WE" represents winter eDNA; "SE" is spring eDNA; "UE" is summer eDNA; "AE" is autumn eDNA;"*" represents $p<0.05$; "***" is $p<0.01$ and “**** is $p<0.001$. Each panel corresponds to an alpha diversity index, identified by the gray area at the top. In each Panel, the abscissa is the grouping label, and the ordinate is the value of the corresponding alpha diversity index; the four colors represent four reasons. The number under the label of diversity index is the $p$ value of the Kruskal-Wallis test.

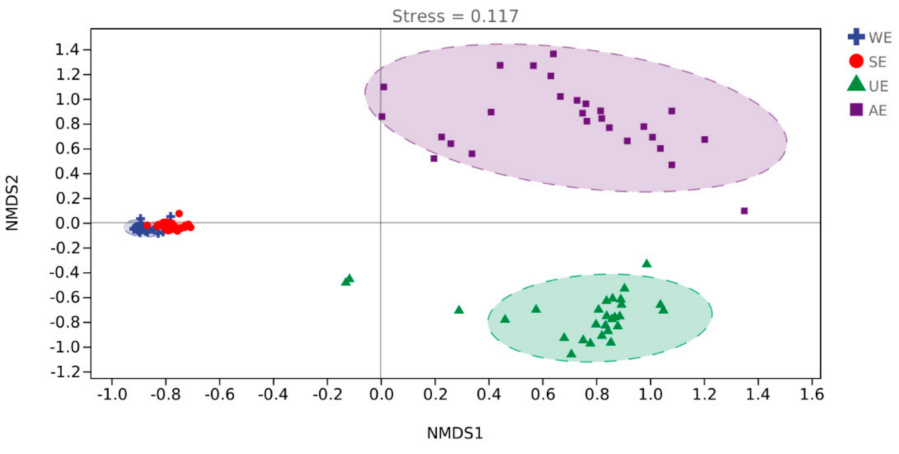

Figure 4. Two-dimensional sorting graph of nonmetric multidimensional scaling analysis (NMDS) analysis. Each point in the diagram represents a sample and different colors indicate different seasons (groups). It can be approximately assumed that the closer (farther) the distance between two points is, the smaller (larger) the difference in microbial community between the two samples is. 


\subsection{Seasonal Variation}

The species composition thermal image showed the difference in assemblage composition among the four seasons in the Yangtze Estuary in 2019 (Figure 5). The image showed that the composition of fish communities in the winter and spring were similar, and they were significantly different from the other two seasons. The species in autumn were the most abundant and the diversity was also high.

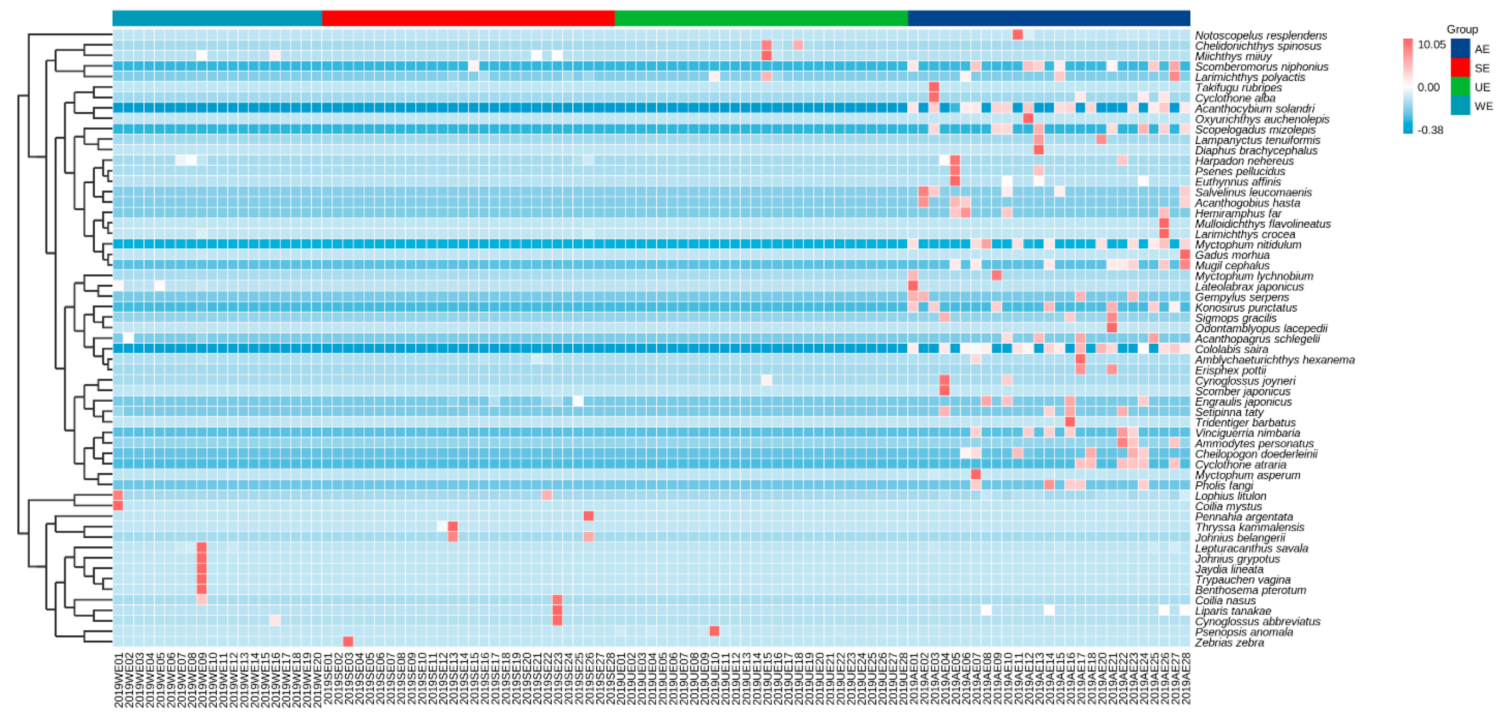

Figure 5. UPGMA shows the difference of assemblage composition. The $X$-axes shows the sampling number; The Y-axes shows the UPGMA clustering that according to the Pearson correlation coefficient matrix of the constituent data and arranged according to the clustering results.

\section{Discussion}

\subsection{Innovations and Improvements to Research Techniques}

Compared with the research in 2018, we improved the statistical analysis of the data using the Personalbio cloud platform analysis [25]. The cloud platform analysis method was used to conduct the grouping and extraction equality analysis of the quarterly samples, which reduced the errors arising from the absence of samples and other problems [45]. The results of the present study also demonstrated that eDNA techniques could be an effective tool to estimate fish species diversity, abundances, biomass, and seasonal spatial distributions in the Yangtze Estuary. Furthermore, our surveys included the winter season, providing a new insight about the annual assessment of fish resources in the Yangtze Estuary.

The key to using eDNA techniques to investigate fish stocks was the amplified primers because ribosomal RNA contains multiple conserved and highly variable regions [46]. In general, primers used to amplify single or multiple variable regions of rRNA genes were used for sequencing and analysis of microbial diversity [47]. In our study, 12S rRNA fragments were used as amplification primers. In 2018, we used eDNA to investigate the Yangtze River Estuary by using the 12S primers proposed by Miya et al. for amplification, and obtained reliable data identification results [25,28]. Since the development of environmental DNA technology, 12S primers are often used to monitor fish amplification studies [25,28]. With the development of eDNA techniques, we found that $16 \mathrm{~S}$ rRNA might be a useful amplification primer [15]. Jeunen et al. used 16S rRNA primer sequencing to investigate the spatial distribution of species at Otago Island, New Zealand [15]. Itakura et al. used eDNA techniques to investigate the spatial distribution of Japanese eels, and 16S rRNA was used to determine the relationship between biomass and abundance. As a result, the distribution trajectory of the Japanese eels was successfully identified [48]. West et al. demonstrated through a study on the biodiversity of Australian coral reefs 
that $16 \mathrm{~S}$ and $18 \mathrm{~S}$ rRNA could be used to target fish, crustaceans and other taxa [16]. The study has shown that $16 \mathrm{~S}$ and $18 \mathrm{~S}$ rRNA have wider applicability; not only can they be applied to fish but they can also be used to identify other vertebrates $[15,16,48]$. In future, we will also consider using different primers to compare the detection effect.

\subsection{Seasonal Variation}

We conducted group analysis and overall comparison of the samples across the whole year, to complete the quarterly comparison [44]. The eDNA abundance measured in the autumn water samples was relatively high; this was similar to the eDNA survey in 2018 [25]. The eDNA abundance in winter was low, which may be related to the overwintering migration of some migratory fish. These migratory fishes, such as Larimichthys crocea, Diaphus brachycephalus, Engraulis japonicus, etc., all entered the Zhoushan fishing grounds and the Yangtze Estuary fishing grounds from March to April, and formed bait groups near the Yangtze Estuary and Lusi fishing grounds from May to June. [49]. Fewer species were detected in summer, which may be because of high summer temperatures and also the easy degradation of eDNA [33]. Previous studies have shown that water temperature, depth, and salinity had a strong impact on the fish assemblage [50]. The composition of species detected in winter and spring was very similar, which might be explained by the similar environmental conditions in these two seasons [50].

In addition to the dominant species, our eDNA techniques analysis also detected relatively rare species, such as the large yellow croaker Larimichthys crocea, which was also identified in 2018 using the eDNA survey of fish resources in the Yangtze Estuary [25]. We also detected the Tiger Puffer Takifugu rubripes, which is listed on the International Union for Conservation of Nature (IUCN) Red List of Endangered Species. This finding is particularly useful in relation to the conservation of the fishery resources in the Yangtze Estuary [25]. The probability of finding an endangered or protected species with traditional survey methods was low, especially if the creature was hidden in an aquatic environment below the surface [6]. By collecting DNA from the environment without direct contact with the detection target, not only can cryptic or rare species be identified, but they will also not be harmed by eDNA techniques, which is beneficial for the protection of some small and more sensitive biological groups [51]. These studies all suggested that eDNA analysis is a useful tool to monitor endangered species.

\subsection{Annual Changes of Fish in the Yangtze Estuary}

Our data results were similar to the traditional survey data of the Yangtze Estuary fish resources (Table 3). Yu identified 48 species from fish captures in the estuary using net surveys in 2010 [52]. Zhang used the same traditional fishing methods to identify 36 species in the estuary in 2004 and 2007, 42 species in 2009 and 2010, and 36 species in 2011 [2]. Because traditional net fishing surveys reflected the dominant species, the species composition varied every time in these studies [25]. A total of 54 species were identified from three seasons (spring, summer, autumn) in 2019. A total of 41 species were identified from three seasons in 2018, with 18 in spring, 12 in summer, and 33 in autumn [25]. The composition of the main species in our study was more consistent compared with the monitoring results of the Yangtze Estuary fish using eDNA in 2018, which further confirmed the reliability of the data. The statistical results show significant differences in the dominant species in the annual variation.

Index of Relative Importance (IRI) of net survey was always used to determine the dominant species, while we used a number of sequences reads in the present study, which resulted in the dominant species being different from the present work compared to other studies [2]. Compared with the survey of fish resources in the Yangtze Estuary in 2018, we developed innovative techniques in data screening and data analysis. The investigation showed that the dominant fish in the Yangtze Estuary had changed. The previous dominant species were significantly reduced, such as Osbeck's grenadier anchovy Coilia mystus, which was only detected in winter in 2019. 
The significant decline of many seasonal fish populations was not only related to environmental factors, but also directly linked to human activities [25], which means that we need to strengthen the protection of the ecological environment. Understanding and monitoring populations are the basis of ecological protection. eDNA techniques provide a low-harm and high-efficiency detection method, which reduces the workload and research costs and improves the efficiency of ecological monitoring [47].

Table 3. Species composition in different years.

\begin{tabular}{|c|c|c|c|}
\hline Year & Species Number & Dominant Species & Method \\
\hline $\begin{array}{c}\text { 1998-2001 } \\
(\text { Yu and Xian, 2010) [52] }\end{array}$ & 48 & $\begin{array}{c}\text { Harpodon nehereus, Benthosemaptero tum, Setipinna taty, Pampus } \\
\text { argenteus, Johnius belengeri }\end{array}$ & Net survey \\
\hline $\begin{array}{l}2004 \text { and 2007 } \\
\text { (Zhang, 2012) [2] }\end{array}$ & 36 & $\begin{array}{l}\text { Trichiurus lepturus, Setipinna taty, Engraulis japonicus, Trachurus } \\
\text { japonicus, Larimichthys polyactis, Scomber japonicus }\end{array}$ & Net survey \\
\hline $\begin{array}{l}2009 \text { and } 2010 \\
(\text { Zhang, 2012) [2] }\end{array}$ & 42 & $\begin{array}{c}\text { Larimichthys crocea, Harpadon nehereus, Miichthys miiuy, Trypauchen } \\
\text { vagina, Coilia nasus, Saurida microlepis, Johnius grypotus, Setipinna taty, } \\
\text { Coilia mystus, Amblychaeturichthys hexanema }\end{array}$ & Net survey \\
\hline $\begin{array}{c}2011 \\
\text { (Zhang, 2012) [2] }\end{array}$ & 36 & Coilia mystus, Larimichthys polyactis & Net survey \\
\hline $\begin{array}{l}2018 \\
(\text { Zhang, 2019) [25] }\end{array}$ & 41 & $\begin{array}{c}\text { Larimichthys crocea, Harpadon nehereus, Miichthys miiuy, Trypauchen } \\
\text { vagina, Coilia nasus, Saurida microlepis, Johnius grypotus, Setipinna taty, } \\
\text { Coilia mystus, Amblychaeturichthys hexanema }\end{array}$ & eDNA \\
\hline $\begin{array}{c}2019 \\
\text { (This study) }\end{array}$ & 58 & $\begin{array}{c}\text { Chelidonichthys spinosus, Engraulis japonicus, Myctophum nitidulum, } \\
\text { Scomberomorus niphonius, Larimichthys polyactis, Acanthocybium solandri, } \\
\text { Cheilopogon doederleinii, Konosirus punctatus }\end{array}$ & eDNA \\
\hline
\end{tabular}

\subsection{The Prospect for Environmental DNA}

The application of eDNA techniques for surveying fish resources in the Yangtze Estuary had obvious advantages compared with the traditional monitoring techniques [22,25]. However, because of the impact of many uncertain factors in the water environment, the determination of biomass of target species needed further research [53]. This research approach also had several limitations, such as water sample pollution, PCR pollution and the effect of uncertainty [9]. This will result in inaccurate environmental DNA survey data, inaccurate results, and irreversible effects on research, etc. Therefore, although eDNA techniques have proven to be very useful, subsequent verification of the findings was also important [19-23,53].

\section{Conclusions}

By examining the seasonal variation in fish resources in the Yangtze Estuary based on eDNA techniques, this investigation will broadly benefit the conservation of the region's fish resources. This study is the first complete quarterly survey of the seasonal variation of fish in the Yangtze Estuary. If eDNA techniques are widely used in surveying species diversity in the Yangtze Estuary area, continuing investigation and the scope of species monitoring will be of great help to the sustainable use of resources and the protection of the ecological environment in this area in the future.

Author Contributions: Conceptualization, H.J., W.X., H.Z.; methodology, H.J., S.Y., W.I., W.X., H.Z.; software, H.J., Y.W., S.Y., W.I.; validation, H.J., Y.W., S.Y., W.I., Y.L.; formal analysis, H.J., S.Y., W.I.; investigation, H.J., Y.W., W.X., H.Z.; resources, W.X. and H.Z.; data curation, S.Y., W.I., H.Z.; writing-original draft preparation, H.J. and H.Z.; writing—review and editing, H.J., Y.W., S.Y., W.I., Y.L., W.X., H.Z.; visualization, H.J., Y.W., Y.L., W.X., H.Z.; supervision, H.Z. All authors have read and agreed to the published version of the manuscript.

Funding: This research was funded by National Natural Science Foundation of China, grant number 41976094 and 31872568; Key Deployment Project of Center for Ocean Mega-Science, Chinese Academy of Sciences, grant number COMS2019Q14; Youth Innovation Promotion Association CAS and the International Partnership Program of Chinese Academy of Sciences, grant number CAS-JSPS, GJHZ1885. The funders had no role in study design, data collection and analysis, decision to publish, or preparation of the manuscript.

Acknowledgments: We would like to thank the editor and all reviewers for the construtive comments on our present study. We thank Leonie Seabrook for proof-reading our English and Personalbio for the technical support.

Conflicts of Interest: The authors declare no conflict of interest. 


\section{References}

1. Zhang, H.; Xian, W.; Liu, S. Ichthyoplankton assemblage structure of springs in the Yangtze Estuary revealed by biological and environmental visions. PeerJ 2015, 3, e1186. [CrossRef] [PubMed]

2. Zhang, Y.Q. Environmental Impact on the Fish Assemblage Structure in Adjacent Sea Area of the Yangtze River Estuary. Master's Thesis, Graduate University of Chinese Academy of Sciences, Beijing, China, 2012.

3. Kindong, R.; Wu, J.; Gao, C.; Dai, L.; Tian, S.; Dai, X.; Chen, J. Seasonal changes in fish diversity, density, biomass, and assemblage alongside environmental variables in the Yangtze River Estuary. Environ. Sci. Pollut. Res. Int. 2020, 27, 25461-25474. [CrossRef] [PubMed]

4. Zhang, H.; Xian, W.; Liu, S. Autumn ichthyoplankton assemblage in the Yangtze Estuary shaped by environmental factors. PeerJ 2016, 4, e1922. [CrossRef] [PubMed]

5. Castañeda, R.A.; Van Nynatten, A.; Crookes, S.; Ellender, B.R.; Heath, D.D.; MacIsaac, H.J.; Mandrak, N.E.; Weyl, O.L.F. Detecting Native Freshwater Fishes Using Novel Non-invasive Methods. Front. Environ. Sci. 2020, 8, 29. [CrossRef]

6. Zou, K.; Chen, J.; Ruan, H.; Li, Z.; Guo, W.; Li, M.; Liu, L. eDNA metabarcoding as a promising conservation tool for monitoring fish diversity in a coastal wetland of the Pearl River Estuary compared to bottom trawling. Sci. Total Environ. 2020, 702, 134704. [CrossRef] [PubMed]

7. Rondon, M.R.; August, P.R.; Bettermann, A.D.; Brady, S.F.; Grossman, T.H.; Liles, M.R.; Loiacono, K.A.; Lynch, B.A.; MacNeil, I.A.; Minor, C.; et al. Cloning the Soil Metagenome: A Strategy for Accessing the Genetic and Functional Diversity of Uncultured Microorganisms. Appl. Environ. Microbiol. 2000, 66, 2541-2547. [CrossRef]

8. Ficetola, G.F.; Miaud, C.; Pompanon, F.; Taberlet, P. Species detection using environmental DNA from water samples. Biol. Lett. 2008, 4, 423-425. [CrossRef]

9. Takahara, T.; Minamoto, T.; Yamanaka, H.; Doi, H.; Kawabata, Z. Estimation of fish biomass using environmental DNA. PLoS ONE 2012, 7, e35868. [CrossRef] [PubMed]

10. Kelly, R.P.; Port, J.A.; Yamahara, K.M.; Crowder, L.B. Using environmental DNA to census marine fishes in a large mesocosm. PLoS ONE 2014, 9, e86175. [CrossRef]

11. Forsstrom, T.; Vasemagi, A. Can environmental DNA (eDNA) be used for detection and monitoring of introduced crab species in the Baltic Sea? Mar. Pollut. Bull. 2016, 109, 350-355. [CrossRef]

12. Stat, M.; Huggett, M.J.; Bernasconi, R.; DiBattista, J.D.; Berry, T.E.; Newman, S.J.; Harvey, E.S.; Bunce, M. Ecosystem biomonitoring with eDNA: Metabarcoding across the tree of life in a tropical marine environment. Sci. Rep. 2017, 7, 12240. [CrossRef]

13. Cowart, D.A.; Murphy, K.R.; Cheng, C.H.C. Metagenomic sequencing of environmental DNA reveals marine faunal assemblages from the West Antarctic Peninsula. Mar. Genom. 2018, 37, 148-160. [CrossRef]

14. Kimmerling, N.; Zuqert, O.; Amitai, G.; Gurevich, T.; Armoza-Zvuloni, R.; Kolesnikov, I.; Berenshtein, I.; Melamed, S.; Gilad, S.; Benjamin, S.; et al. Quantitative species-level ecology of reef fish larvae via metabarcoding. Nat. Ecol. Evol. 2018, 2, 306-316. [CrossRef] [PubMed]

15. Jeunen, G.J.; Knapp, M.; Spencer, H.G.; Lamare, M.D.; Taylor, H.R.; Stat, M.; Bunce, M.; Gemmell, N.J. Environmental DNA (eDNA) metabarcoding reveals strong discrimination among diverse marine habitats connected by water movement. Mol. Ecol. Resour. 2019, 19, 426-438. [CrossRef] [PubMed]

16. West, K.M.; Stat, M.; Harvey, E.S.; Skepper, C.L.; DiBattista, J.D.; Richards, Z.T.; Travers, M.J.; Newman, S.J.; Bunce, M. eDNA metabarcoding survey reveals fine-scale coral reef community variation across a remote, tropical island ecosystem. Mol. Ecol. 2020, 29, 1069-1086. [CrossRef] [PubMed]

17. Thomsen, P.F.; Willerslev, E. Environmental DNA-An emerging tool in conservation for monitoring past and present biodiversity. Biol. Conserv. 2015, 183, 4-18. [CrossRef]

18. Thalinger, B.; Wolf, E.; Traugott, M.; Wanzenbock, J. Monitoring spawning migrations of potamodromous fish species via eDNA. Sci. Rep. 2019, 9, 15388. [CrossRef]

19. Yamanaka, H.; Minamoto, T. The use of environmental DNA of fishes as an efficient method of determining habitat connectivity. Ecol. Indic. 2016, 62, 147-153. [CrossRef]

20. Mauvisseau, Q.; Davy-Bowker, J.; Bulling, M.; Brys, R.; Neyrinck, S.; Troth, C.; Sweet, M. Combining ddPCR and environmental DNA to improve detection capabilities of a critically endangered freshwater invertebrate. Sci. Rep. 2019, 9, 14064. [CrossRef] 
21. Evans, N.T.; Olds, B.P.; Renshaw, M.A.; Turner, C.R.; Li, Y.; Jerde, C.L.; Mahon, A.R.; Pfrender, M.E.; Lamberti, G.A.; Lodge, D.M. Quantification of mesocosm fish and amphibian species diversity via environmental DNA metabarcoding. Mol. Ecol. Resour. 2016, 16, 29-41. [CrossRef]

22. Lacoursière-Roussel, A.; Côté, G.; Leclerc, V.; Bernatchez, L.; Cadotte, M. Quantifying relative fish abundance with eDNA: A promising tool for fisheries management. J. Appl. Ecol. 2016, 53, 1148-1157. [CrossRef]

23. Doi, H.; Inui, R.; Akamatsu, Y.; Kanno, K.; Yamanaka, H.; Takahara, T.; Minamoto, T. Environmental DNA analysis for estimating the abundance and biomass of stream fish. Freshw. Biol. 2017, 62, 30-39. [CrossRef]

24. Harrison, J.B.; Sunday, J.M.; Rogers, S.M. Predicting the fate of eDNA in the environment and implications for studying biodiversity. Proc. Biol. Sci. 2019, 286, 20191409. [CrossRef] [PubMed]

25. Zhang, H.; Yoshizawa, S.; Iwasaki, W.; Xian, W. Seasonal Fish Assemblage Structure Using Environmental DNA in the Yangtze Estuary and Its Adjacent Waters. Front. Mar. Sci. 2019, 6, 515. [CrossRef]

26. Sigsgaard, E.E.; Torquato, F.; Froslev, T.G.; Moore, A.B.M.; Sorensen, J.M.; Range, P.; Ben-Hamadou, R.; Bach, S.S.; Moller, P.R.; Thomsen, P.F. Using vertebrate environmental DNA from seawater in biomonitoring of marine habitats. Conserv. Biol. 2020, 34, 697-710. [CrossRef]

27. General Administration of Quality Supervision; Inspection and Quarantine of the People's Republic of China and Standardization Administration of China. Specifications for Oceanographic Survey; China Standard Press: Beijing, China, 2007; p. 3.

28. Miya, M.; Sato, Y.; Fukunaga, T.; Sado, T.; Poulsen, J.Y.; Sato, K.; Minamoto, T.; Yamamoto, S.; Yamanaka, H.; Araki, H.; et al. MiFish, a set of universal PCR primers for metabarcoding environmental DNA from fishes: Detection of more than 230 subtropical marine species. R. Soc. Open Sci. 2015, 2, 150088. [CrossRef]

29. Bokulich, N.A.; Subramanian, S.; Faith, J.J.; Gevers, D.; Gordon, J.I.; Knight, R.; Mills, D.A.; Caporaso, J.G. Quality-filtering vastly improves diversity estimates from Illumina amplicon sequencing. Nat. Methods 2013, 10,57-59. [CrossRef]

30. Magoc, T.; Salzberg, S.L. FLASH: Fast length adjustment of short reads to improve genome assemblies. Bioinformatics 2011, 27, 2957-2963. [CrossRef]

31. Camacho, C.; Coulouris, G.; Avagyan, V.; Ma, N.; Papadopoulos, J.; Bealer, K.; Madden, T.L. BLAST+: Architecture and applications. BMC Bioinform. 2009, 10, 421. [CrossRef]

32. Sato, Y.; Miya, M.; Fukunaga, T.; Sado, T.; Iwasaki, W.; Kumar, S. MitoFish and MiFish Pipeline: A Mitochondrial Genome Database of Fish with an Analysis Pipeline for Environmental DNA Metabarcoding. Mol. Biol. Evol. 2018, 35, 1553-1555. [CrossRef]

33. Edgar, R.C.; Haas, B.J.; Clemente, J.C.; Quince, C.; Knight, R. UCHIME improves sensitivity and speed of chimera detection. Bioinformatics 2011, 27, 2194-2200. [CrossRef] [PubMed]

34. Edgar, R.C. Search and clustering orders of magnitude faster than BLAST. Bioinformatics 2010, 26, 2460-2461. [CrossRef] [PubMed]

35. Zhuang, P.; Wang, Y.H.; Li, S.F.; Deng, S.M.; Li, C.S.; Ni, Y. Fishes in the Yangtze Estuary; China Agricultural Press: Beijing, China, 2018.

36. Whittaker, R.H. Vegetation of the siskiyou mountains, oregon and california. Ecol. Monogr. 1960, 30, $279-338$. [CrossRef]

37. Whittaker, R.H. Evolution and measurement of species diversity. Taxon 1972, 21, 213-251. [CrossRef]

38. Chao, A. Nonparametric Estimation of the Number of Classes in a Population. Scand. J. Stat. 1984, 11, 265-270.

39. Legovic, T. Statistical ecology. A primer on methods and computing. Ecol. Model. 1991, 54, 143-144.

40. Faith, D.P. Conservation evaluation and phylogenetic diversity. Biol. Conserv. 1992, 61, 1-10. [CrossRef]

41. Anderson, M.J.; Ellingsen, K.E.; McArdle, B.H. Multivariate dispersion as a measure of beta diversity. Ecol. Lett. 2006, 9, 683-693. [CrossRef]

42. Lozupone, C.A.; Knight, R. Species divergence and the measurement of microbial diversity. FEMS Microbiol. Rev. 2008, 32, 557-578. [CrossRef]

43. Bokulich, N.A.; Kaehler, B.D.; Rideout, J.R.; Dillon, M.; Bolyen, E.; Knight, R.; Huttley, G.A.; Gregory Caporaso, J. Optimizing taxonomic classification of marker-gene amplicon sequences with QIIME 2's q2-feature-classifier plugin. Microbiome 2018, 6, 90. [CrossRef]

44. Faust, K.; Raes, J. Microbial interactions: From networks to models. Nat. Rev. Microbiol. 2012, 10, 538-550. [CrossRef] [PubMed] 
45. Bastian, M.; Heymann, S.; Jacomy, M. Gephi: An open source software for exploring and manipulating networks. Icwsm 2009, 8, 361-362.

46. Langille, M.G.; Zaneveld, J.; Caporaso, J.G.; McDonald, D.; Knights, D.; Reyes, J.A.; Clemente, J.C.; Burkepile, D.E.; Vega Thurber, R.L.; Knight, R.; et al. Predictive functional profiling of microbial communities using 16S rRNA marker gene sequences. Nat. Biotechnol. 2013, 31, 814-821. [CrossRef] [PubMed]

47. Wood, S.A.; Biessy, L.; Latchford, J.L.; Zaiko, A.; von Ammon, U.; Audrezet, F.; Cristescu, M.E.; Pochon, X. Release and degradation of environmental DNA and RNA in a marine system. Sci. Total. Environ. 2020, 704, 135314. [CrossRef] [PubMed]

48. Itakura, H.; Wakiya, R.; Yamamoto, S.; Kaifu, K.; Sato, T.; Minamoto, T. Environmental DNA analysis reveals the spatial distribution, abundance, and biomass of Japanese eels at the river-basin scale. Aquat. Conserv. Mar. Freshw. Ecosyst. 2019, 29, 361-373. [CrossRef]

49. Sun, P.F.; Dai, F.Q.; Chen, Y.L.; Shan, X.J.; Jin, X.S. Seasonal Variations in Structure of Fishery Resource in the Yangtze River Estuary and Its Adjacent Waters. Prog. Fish. Sci. 2015, 36, 8-16.

50. Morais, P.; Chicharo, M.A.; Chicharo, L. Changes in a temperate estuary during the filling of the biggest European dam. Sci. Total Environ. 2009, 407, 2245-2259. [CrossRef] [PubMed]

51. Wood, S.A.; Pochon, X.; Laroche, O.; von Ammon, U.; Adamson, J.; Zaiko, A. A comparison of droplet digital polymerase chain reaction (PCR), quantitative PCR and metabarcoding for species-specific detection in environmental DNA. Mol. Ecol. Resour. 2019, 19, 1407-1419. [CrossRef]

52. Yu, H.C.; Xian, W.W. Fish assemblage structure in adjacent Sea of Yangtze Estuary and its relationship with environmental factors. J. Yangtze River Sci. Res. Inst. 2010, 27, 88-92.

53. Mariani, S.; Baillie, C.; Colosimo, G.; Riesgo, A. Sponges as natural environmental DNA samplers. Curr. Biol. 2019, 29, R401-R402. [CrossRef]

Publisher's Note: MDPI stays neutral with regard to jurisdictional claims in published maps and institutional affiliations. 